\title{
Morphological Characteristics and Motor Fitness Among Girls Attending Different Secondary-School Programmes
}

\author{
Características Morfológicas y Estado Físico Motor entre Niñas que Asisten a Diferentes Programas de Escuelas \\ Secundarias
}

Marjeta Kovac; Janko Strel; Gregor Jurak \& Bojan Leskosek

KOVAC, M.; STREL, J.; JURAK, G. \& LESKOSEK, B. Morphological characteristics and motor fitness among girls attending different secondary-school programmes. Int. J. Morphol., 30(2):411-416, 2012.

SUMMARY: During adolescence, a drop of interest in physical activity in girls' free time and a stagnation in some physical fitness indicators can be observed. The physical fitness of a sample of 14,920 girls from three different types of secondary-school educational programmes (academic, technical and vocational) with different amounts of physical education lessons in the curriculum was analysed. Data from the Slovenia's monitoring system of students' physical fitness (SLOFIT), including three morphological measures and eight motor tests, was used. A multivariate analysis of variance was used to test the differences between the type of programme and the age of students. There are statistically significant $(\mathrm{p}<0.001)$ differences between the educational programmes for the entire set of tested morphological and motor variables. The educational programme is a much more important factor (about $7 \%$ of explained variances) than age $(0.4 \%)$. It better explains the differences in motor variables than morphological variables. Girls from the academic programme are taller and have thinner triceps skinfolds. They also show better motor fitness than their counterparts from technical and vocational programmes. However, it cannot be concluded that all the variability is due to the secondary-school educational programme, because the results are also influenced by some interpersonal and social factors that were not controlled in our study. Nevertheless, more action is needed to compensate certain inequalities between young girls, especially those from vocational schools.

KEY WORDS: Anthropometry; Motor tests; Female; Adolescence.

\section{INTRODUCTION}

The physical fitness of young people is mostly influenced by their amount of physical activity. Physical activity is influenced by three domains: intrapersonal (biological, psychological and behavioural influences), social (family or peer support, modelling), and environmental (facilities, communities, accessibility etc.) (Sallis \& Owen, 1999). There are significant interactions between these factors. Thus, better physical fitness of young people is positively related to higher levels of physical activity (Dwyer et al., 2001), higher academic achievement (Dwyer et al.; Nelson \& Gordon-Larskson, 2006) and better cognitive functioning (Sibley \& Etnier, 2003). The results of many research studies have also showed that the level of one's parents' education and the social status of one's family have a particular impact on the amount of free-time physical activity (Fairclough et al., 2009; La Torre et al., 2006; Westerstahl et al., 2005).

Adolescence is one of the most turbulent periods of an individual's life, since major biological, psychological and sociological changes involved prepare young people to enter adulthood (Pratt, 2005). During the period of late adolescence a stagnation and even a decrease in some fitness components can be observed among girls, especially with regard to general endurance (Ortega et al., 2008; Strel et al., 2007). Studies have consistently shown a decline in girls' physical activity with age, at least during the teen years (Armstrong \& Welsman, 2006; Riddoch et al., 2004). The main reasons for this are the different interests of adolescents (Sallis et al., 1992). This drop of interest in physical activity in one's free time is a matter of significant concern, since it is generally acknowledged that physical activity has several benefits that improve the health status and quality of life of adolescents (Ortega et al.).

Secondary-school education in Slovenia includes the population between the ages of 15 and 19. In this period, students attain general education in the four-year-long academic programme in preparation for university, or prepare for work in the four-year-long technical, and two- or three-year-long vocational programmes.

University of Ljubljana, Faculty of Sport, Gortanova 22, 1000 Ljubljana, Slovenia. 
Physical education (PE) is a compulsory subject in all types of Slovenian secondary schools; however, the various educational programmes contain different amounts of PE lessons per week: one or two hours in vocational programmes, two or three hours in technical programmes, and three hours in academic programmes. The purpose of the secondary-school PE curriculum is to influence the fitness level of young people and to form a healthy lifestyle through positive attitudes to free-time participation in moderate and vigorous physical activities (Kovac et al., 2011). Slovenian researchers found that compulsory PE is the only physical activity of at least moderate intensity undertaken by many young Slovenian people, particularly for girls in vocational programmes (Jurak, 2006; Kovac et al.; Strel et al.). In Sweden, Westerstahl et al. found that 16-year-old students who attended practical programmes were less physically fit than students in academic programmes. Their lower fitness was associated with a lower socio-economic status, a lower perceived positive influence of one's parents to be physically active, as well as a lower level of perceived health.

The purpose of this study is to identify differences in morphological characteristics and motor fitness among girls, according to their age and attended educational programme.

\section{MATERIAL AND METHOD}

In the 2010/2011 school year, the Slovenian cohort included 20,314 girls (73.4\% of the girls attending first three years of different secondary-school programmes) who enrolled in the SLOFIT system, Slovenia's monitoring system of student's physical fitness, with their written consent. Only healthy students were tested in April 2011. Due to the varying lengths of the academic courses, the comparison focused only on 16-, 17- and 18-year-old girls, as this is the age when all secondary-school students attend one of the three educational programmes. The analysed subsample consisted of 14,920 girls: 8,564 from academic programmes, 5,302 from technical programmes, and 1,054 from vocational programmes.

The test battery includes three morphological measures (body height, body weight and triceps skinfold thickness) and eight tests of motor fitness: arm plate tapping (measuring for speed of alternate movement), standing long jump (explosive power of legs), backwards obstacle course (co-ordination of the whole body movement), sit-ups (strength of abdominal muscles), standing reach touch (flexibility), bent arm hang (muscular endurance of the shoulder girdle and arms), 60-metre run (sprint speed), and 600-metre run (general endurance). Measurements have been carried out systematically every year in April by PE teachers during PE lessons in all Slovenian schools since 1986. In this manner, data regarding more than $80 \%$ of secondaryschool students has been collected (Strel et al.).

The data were analysed using the PASW Statistics 18.0 statistical package. Basic parameters of the distribution of variables were calculated (mean, standard deviation). In girls with one or two missing values in any of morphological or motor tests, data were imputed using an EM algorithm. A multivariate analysis of variance (MANOVA) was used to test the differences between the programmes and the age of students. The amount of explained variance of the entire system of dependent variables was estimated with a partial $\eta^{2}$ separately for both main effects (programme, age) and their two-way interaction. Univariate tests were also carried out for each dependent variable separately: F-tests for the entire model, for both main effects and their interaction were applied.

\section{RESULTS AND DISCUSSION}

With this study, we were able to show the differences in some morphological characteristics and motor tests performance in girls attending different secondary-school educational programmes. The main finding is that girls from the academic programme showed better physical fitness than their counterparts from technical and vocational programmes.

AMANOVA shows that the type of secondary-school educational programme significantly explains (Wilks' Lambda $=.866, \mathrm{p}<.001$, partial $\eta^{2}=.069$ ) the differences between the three groups of educational programmes in set of selected variables, whereas the age (partial $\left.\eta^{2}=.004\right)$ and the two-way interaction between age and programmes (partial $\eta^{2}=.001$ ) are negligible, although still statistically significant ( $\mathrm{p}<.001)$. Therefore, the educational programme factor has a significantly stronger influence than the age. This coincides with various other studies stating that educational aspirations of individuals, besides of the socioeconomic status of one's family and the education level of one's parents, have a significant influence on the motor fitness of young people (Jurak; La Torre et al.; Westerstahl et al.).

Considerable and consistent differences in morphological parameters between the educational programmes can be observed (Fig. 1, upper part), except for 17-year-old girls from vocational programmes, who have similar body weight as the girls from technical programmes, 
KOVAC, M.; STREL, J.; JURAK, G. \& LESKOSEK, B. Morphological characteristics and motor fitness among girls attending different secondary-school programmes.

Int. J. Morphol., 30(2):411-416, 2012.
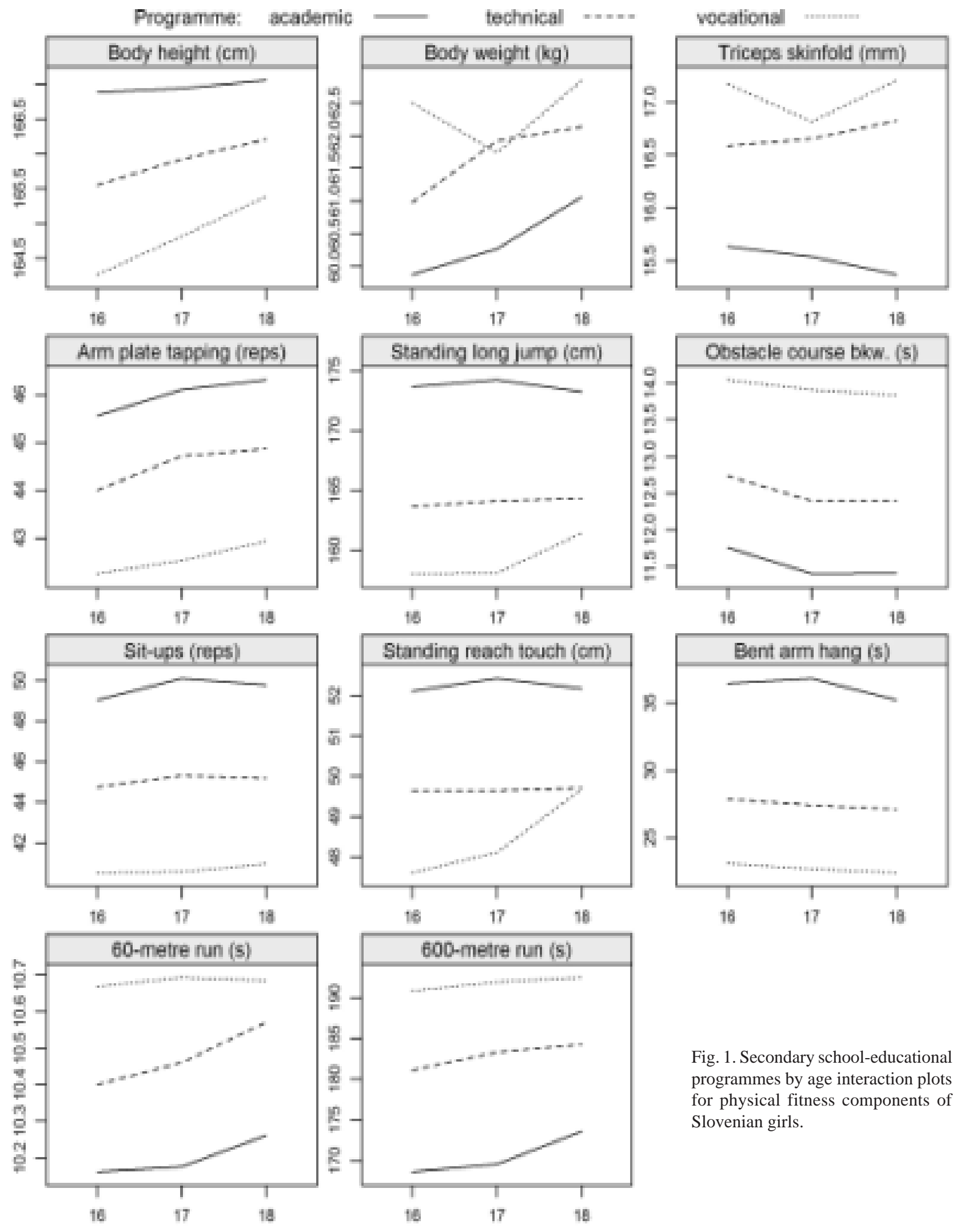

Age (years)

Fig. 1. Secondary school-educational programmes by age interaction plots for physical fitness components of Slovenian girls. 
but otherwise are smaller, heavier and have more subcutaneous body fat than their counterparts from academic and technical programmes.

The changes in morphological characteristics of girls between the ages of 16 and 18 are generally in agreement with known patterns (Malina et al., 2004). Although longitudinal growth is mainly genetically determined (Sinclair, 1978), it is also affected by the available energy supplies, the level of excretion of growth hormone $(\mathrm{GH})$ and some other anabolic hormones (Rogol et al., 2000) and the socioeconomic status of family (Jürimäe \& Jürimäe, 2000). Girls from academic programmes are on average considerably taller than their counterparts from technical programmes, who are (in turn) taller than girls from vocational programmes. It is possible that the differences between the girls from the various programmes occur due to the differences in dietary habits, i.e. it has been found that the students in vocational programmes have a poorer diet, with their meals being less regular compared to the students in four-year-long educational programmes (Fidler Mis et al., 2009).

Girls from the academic programmes achieved the smallest mean value of body weight and triceps skinfold thickness. The reasons for the differences between the programmes are probably similar to the differences in body height. However, the increase of body mass and subcutaneous fatty tissue in contemporary youth has been observed by several researchers (Fairclough et al.; Starc \& Strel, 2011). As expected, the body weight of girls in 2011 was higher than ten and twenty years ago (Starc \& Strel; Strel et al.). In the year 2000, the average body weight of 18 -year-old Slovenian girls was $59.4 \mathrm{~kg}(0.5$ more than in 1990 and $1.2 \mathrm{~kg}$ less than in 2011). The average triceps skinfold thickness values of 18-year-old girls was $14.4 \mathrm{~mm}$ in 1990 and $14.1 \mathrm{~mm}$ in the year 2000 (Strel et al.), whereas in our subsample in 2011 these values were $15.4 \mathrm{~mm}$ in girls from the academic programmes, $16.8 \mathrm{~mm}$ in girls from the technical programmes and $17.2 \mathrm{~mm}$ in girls from the vocational programmes.

All tested groups of educational programmes also significantly vary in motor fitness, since the educational programme better explains the differences in motor variables than in morphological ones (Table I). The girls from academic programmes achieved the best results in all tests in all age groups compared to the girls from other two programmes. Similarly, the girls in technical programmes achieved better results than the girls in vocational programmes (Fig. 1, lower part). The particularly good physical fitness of the academic school girls is presumably a result of more favourable socio-economic environments (Flere et al., 2010).
Univariate tests of the differences between the groups (Table I) show that the biggest differences between the groups were observed in the tests sit-ups, 600-m run, obstacle course backwards and standing long jump. On the basis of other researchers' findings, the availability of PE due to the different amounts of lessons in individual educational programmes is not the only factor. Therefore, such major differences could also be explained by interpersonal factors: background to the working of functional mechanisms responsible for the efficiency of the execution of the test tasks (Jürimäe \& Jürimäe); longer lasting activity requires motivation of the measured subjects to carry out the task (Dwyler et al.), as well as by social and environmental factors: socio-economic status and positive attitudes to healthy lifestyle of one's parents, which results in more frequent participation in free-time sports activities (Fairclough et al.; La Torre et al.; Westerstahl et al.).

The results of measured variables of motor fitness improve only slightly with age in all three groups (see Fig. 1, lower part), except for the 60-metre run and endurance tests (bent arm hang; 600-metre run). This only slight improvement or even stagnation of motor fitness in girls has been detected in several studies (Ortega et al.; Strel et al.).

We can conclude that girls from different secondaryschool programmes are dissimilar not only in the level of their academic achievements (Flere et al.) but also in their morphological status and motor fitness. Special attention should be given to the contributions of PE and out-of school sport programmes for girls attending vocational programmes.

Limitations. There are limitations to our study, and care should be taken in generalising, since there are differences in the organisation and contents of PE curricula worldwide. The study did not control for many important environmental and social factors influencing the physical and motor development of girls. We were also unable to gather the information on teachers actual PE planning and teaching competencies, which surely influence the quality of curriculum delivery.

KOVAC, M.; STREL, J.; JURAK, G. \& LESKOSEK, B. Características morfológicas y estado físico motor entre niñas que asisten a diferentes programas de escuelas secundarias. Int. J. Morphol., 30(2):411-416, 2012.

RESUMEN: Durante la adolescencia, se puede observar una baja de interés en la actividad física en el tiempo libre de las 
Table I. Univariate F-test significances and proportions of explained variance for the full model and model effects

\begin{tabular}{lcccccccc}
\hline & \multicolumn{9}{c}{ Source of variation } \\
\cline { 2 - 9 } & \multicolumn{2}{c}{ Full model } & \multicolumn{1}{c}{ School programme } & \multicolumn{2}{c}{ Age } & \multicolumn{2}{c}{ School programme *Age } \\
& $\mathbf{p}$ & $\boldsymbol{\eta}^{2}$ & $\mathbf{p}$ & $\boldsymbol{\eta}^{2}$ & $\mathbf{p}$ & $\boldsymbol{\eta}^{2}$ & $\mathbf{p}$ & $\boldsymbol{\eta}^{2}$ \\
\hline Body height & $<.001$ & $1.4 \%$ & $<.001$ & $1.2 \%$ & .002 & $.09 \%$ & .196 & $.04 \%$ \\
Body weight & $<.001$ & $.7 \%$ & $<.001$ & $.5 \%$ & .010 & $.06 \%$ & .210 & $.04 \%$ \\
Triceps skinfold thickness & $<.001$ & $1.2 \%$ & $<.001$ & $1.2 \%$ & .648 & $.01 \%$ & .261 & $.04 \%$ \\
Arm plate tapping & $<.001$ & $4.3 \%$ & $<.001$ & $3.7 \%$ & $<.001$ & $.19 \%$ & .797 & $.01 \%$ \\
Standing long jump & $<.001$ & $5.3 \%$ & $<.001$ & $5.1 \%$ & .211 & $.02 \%$ & .170 & $.04 \%$ \\
Obstacle course backwards & $<.001$ & $5.8 \%$ & $<.001$ & $5.4 \%$ & $<.001$ & $.11 \%$ & .913 & $.01 \%$ \\
Sit-ups & $<.001$ & $7.5 \%$ & $<.001$ & $7.3 \%$ & .078 & $.03 \%$ & .576 & $.02 \%$ \\
Standing reach touch & $<.001$ & $3.7 \%$ & $<.001$ & $3.5 \%$ & .004 & $.07 \%$ & .009 & $.09 \%$ \\
Bent arm hang & $<.001$ & $4.6 \%$ & $<.001$ & $4.4 \%$ & .397 & $.01 \%$ & .723 & $.01 \%$ \\
60-metre run & $<.001$ & $2.6 \%$ & $<.001$ & $2.3 \%$ & .011 & $.06 \%$ & .338 & $.03 \%$ \\
600-metre run & $<.001$ & $6.1 \%$ & $<.001$ & $5.6 \%$ & .001 & $.09 \%$ & .116 & $.05 \%$ \\
\hline
\end{tabular}

niñas y el estancamiento en algunos indicadores de la condición física. Se analizó la condición física de una muestra de 14.920 niñas de escuelas secundarias de tres tipos diferentes de programas educativos (académica, técnica y profesional) con diferentes cantidades de clases de educación física en el curriculum. Se utilizaron los datos del sistema de monitoreo de aptitud física de estudiantes de Eslovenia (SLOFIT), incluyendo tres medidas morfológicas y ocho pruebas motoras. Se utilizó un análisis multivariado de varianza para probar las diferencias entre el tipo de programa y la edad de los estudiantes. Las diferencias entre los programas de educación para todo el conjunto de las variables morfológicas y motoras analizadas no fueron estadísticamente significativas ( $\mathrm{p}<0,001)$. El programa educativo es un factor mucho más importante (explica alrededor del $7 \%$ de la varianza) que la edad $(0,4 \%)$. Se explican mejor las diferencias en las variables motoras que las morfológicas. Las niñas del programa académico son más altas y tienen el pliegue cutáneo del tríceps más delgado. También muestran un mejor estado físico motor que sus contrapartes de los programas de formación técnica y profesional. Sin embargo, no se puede concluir que toda la variabilidad se debe al programa educativo de enseñanza secundaria, ya que los resultados también son influenciados por algunos factores personales y sociales que no fueron controlados en nuestro estudio. Sin embargo, es necesario actuar más para compensar ciertas desigualdades entre las niñas adolescentes, especialmente en las escuelas de formación profesional.

PALABRAS CLAVE: Antropometría; Prueba motora; Mujeres; Adolescencia.

\section{REFERENCES}

Armstrong, N. \& Welsman, J. R. The physical activity patterns of European youth with reference to methods of assessment. Sports Med., 36(12):1067-86, 2006.
Dwyer, T.; Sallis, J. F.; Blizzard, L.; Lazarus, R. \& Dean, K. Relation of academic performance to physical activity and fitness in children. Pediatr. Exerc. Sci., 13:225-38, 2001.

Fairclough, S. J.; Boddy, L. M.; Hackett, A. F. \& Stratton, G. Associations between children's socioeconomic status, weight status, and sex, with screen-based sedentary behaviours and sport participation. Int. J. Pediatric Obes., 4:299-305, 2009.

Fidler Mis, N.; Kobe, H.; Stimec, M. \& Krzisnik, C. Dietary habits of Slovenian adolescents. Med. Razgl., 48:126, 2009.

Flere, S.; Tavcar Krajnc, M.; Klanjsek, R.; Musil, B. \& Kirbis, A. Cultural capital and intellectual ability as predictors of scholastic achievement: a study of Slovenian secondary school students. Br. J. Sociol. Educ., 31(1):47-58, 2010.

Jurak, G. Sports vs. the »cigarettes \& coffee « lifestyle of Slovenian high-school students. Anthrop. Notebooks, 12(2):79-95, 2006.

Jürimäe, T. \& Jürimäe, J. Growth, physical activity and motor development in prepubertal children. Boca Raton, CRC Press LLC, 2000.

Kovac, M.; Jurak, G.; Starc, G. \& Strel, J. The Importance of Research-based Evidence for Political Decisions on Physical Education. In: Hardman, K. \& Green, K. (Eds.) Contemporary Issues in Physical Education: international Perspectives. Auckland, Meyer \& Meyer Sport, 2011. pp.47-68.

La Torre, G.; Masala, D.; De Vito, E.; Langiano, E.; Capelli, G.; Ricciardi, W. \& PHASES collaborative group. Extra-curricular physical activity and socioeconomic status in Italian adolescents. BMC Public Health, 6:22, 2006.

Malina, R. M.; Bouchard, C. \& Bar-Or, O. Growth, maturation and physical activity. 2nd Ed. Champaign, IL, Human Kinetics, 2008. 
Nelson, M. C. \& Gordon-Larsen, P. Physical activity and sedentary behavior patterns are associated with selected adolescent health risk behaviors. Pediatrics, 117(4):1281-90, 2006.

Ortega, F. B.; Ruiz, J. R.; Castillo, M. J. \& Sjöström, M. Physical fitness in childhood and adolescence: a powerful marker of health. Int. J. Obes., 32(1):1-11, 2008.

Pratt, H. D. Adolescence. Encyclopedia of Human Development. SAGE Publications, 2005. Available in: http://sageereference.com/humandevelopment/Article_n12.html.

Riddoch, C. J.; Andersen, L. B.; Wedderkopp, N.; Harro, M.; Klasson-Heggebo, L.; Sardinha, L. B.; Cooper, A. R. \& Ekelund, U. Physical activity levels and patterns of 9- and 15yr-old European children. Med. Sci. Sports Exerc., 36(1):8692, 2004.

Rogol, A. D.; Clark, P. A. \& Roemmich, J. N. Growth and pubertal development in children and adolescents: effects of diet and physical activity. Am. J. Clin. Nutr., 72(2):521S-8S, 2000.

Sallis, J. F. \& Owen, N. Physical activity and behavioral medicine. Thousand Oaks, CA, Sage, 1999.

Sallis, J. F.; Simons-Morton, B. G.; Stone, E. J.; Corbin, C. B.; Epstein, L. H.; Faucette, N.; Iannotti, R. J.; Killen, J. D.; Klesges, R. C.; Petray, C. K.; et al. Determinants of physical activity and interventions in youth. Med. Sci. Sports Exerc., 24(6):S248-57, 1992.

Sibley, B. A. \& Etnier, J. L. The relationship between physical activity and cognition in children: A meta-analysis. Pediatr. Exerc. Sci., 15:243-56, 2003.

Sinclair, D. Human growth after birth. London, Oxford University Press, 1978.

Starc, G. \& Strel, J. Tracking excess weight and obesity from childhood to young adulthood: a 12-year prospective cohort study in Slovenia. Public. Health Nutr., 14(1):49-55, 2011.

Strel, J.; Kovac, M. \& Jurak, G. Physical and motor development, sport activities and lifestyles of Slovenian children and youth - changes in the last few decades. In: Brettschneider, W. D. \& Naul, R. Obesity in Europe: young people's physical activity and sedentary lifestyles. Sport Sciences International, $\mathrm{N}^{\circ} 4$. Frankfurt am Main, Peter Lang, 2007. pp.243-64.

Westerstahl, M.; Barnekow-Bergkvist, M. \& Jansson E. Low physical activity among adolescents in practical education. Scand. J. Med. Sci. Spor., 15(5):287-97, 2005.
Correspondence to:

Assoc. Prof. Marjeta Kovac, PhD

University of Ljubljana, Faculty of Sport

Gortanova 22

1000 Ljubljana

Slovenia

Phone: + 386015207737

Fax: + 386015207740

Email: marjeta.kovac@fsp.uni-lj.si

Received: 16-12-2011

Accepted: 20-01-2012 